Anr. Sci. forest., 1980, 37 (4), 299-306.

\title{
Population trends of Cryptococcus fagisuga Lindinger following different thinning intensities of young beech
}

\author{
E. J. PARKER \\ Forestry Commission, Forest Research Station, \\ Alice Holt Lodge, Wrecelesham, Farnham, \\ Surrey, GU10 4LH, U. K.
}

\begin{abstract}
Summary
Infestations of $C_{\text {ryptococcus fagisuga, and other symptoms of beech bark disease, were recorded }}$ annually for eight years, in plots following different thinning regimes. The iniensity of thinning had no apparent effect on the increase of $C$. fagisuga within a stand. Increase of $C$. fagisuga on individual trees occurred irrespective of their diameter. Competition within a crop may help BBD to kill more trees through lowered host resistance. It is suggested that BBD losses in young stands are recouped in a few years by compensatory growth of surviving trees.
\end{abstract}

\section{Introduction}

Thinning of beech, Fagus sylvatica L., is a necessary silvicultural treatment when plantations reach an age of approximately 30 years. Thinning may also be regarded as an operation whereby deformed or diseased trees can be selecitively removed from a stand. However, conflicting opinions based often on observations or subjective data rather than experimental results, have been advanced as to the effects of thinning on the subsequent course of beech bark disease (BBD). Whether or not opening up the crop disturbs the microenvironment to the detriment of the causal organisms of $B B D$, or whether host tree resistance is lowered as a result of a sudden local environmental change, is uncertain. It is also not clear whether associated organisms are favoured by an improvement in the nutritional status of the host trees following thinning. The interpretation of observations is not straighrforward because of the dificulty in separating the effects of thinning from other factors such as age of crop, density of the stand, and site conditions. Even when this complex of interacting factors is taken into account, it is still not clear whether the effect on populations of the felted beech scale, Cryptococcus fagisuga Lindinger, occurs through a direct physical influence on host resistance to infestation, or indirectly by affecting the ecology of the bark 
surface environment through moisture retention, the relative growth of bark microflora, and the degree of shelter afforded (Ehrlich, 1934).

The designation of this insect as $C$. fagisuga is considered to be correct and thus it should replace $C$. fagi (Baerensprung) as the taxonomically valid name (Lindinger, 1936). The specific epithet is derived from the Latin, fagus = beech, and sugere $=$ to suck.

From earlier investigations in southern England (Parker, 1974, 1975) it was evident that BBD outbreaks could build-up in a crop at an age prior to first thinning. Early attacks of this kind, at about 25 years of age, occurred particularly where crops grew well. In some stands where BBD attack developed after a first thinning, it was uncertain as to whether this reflected the natural course of BBD with time, or resulted from the effects of thinning. In Belgium, an overcrowded crop was considered to be an important factor in the development of a disease outbreak by fostering the spread of the scale insect, whilst suitable thinnings resulted in a decline of the insect populations (Duchesne, 1909). In natural mixed hardwood forest in N. America, Ehrlich (1934), and Barter (1947), found a small positive correlation of disease incidence with percentage of beech ( $F$. grandifolia Ehrh.) in a stand. Peace (1954) suggested that in Great Britain a history of underthinning in beech was a contributory factor in disease incidence leading probably to greater competition among individuals in a stand. Crosby and Bjorkbom (1958) reported evidence from experimental work that showed no marked effect on progress of the disease by opening up a mixed stand of uneven age, by felling other species to remove 20 to 50 p. 100 basal area, although there was some indication that heavy thinning by removal of about one half the basal area resulted in a slight reduction in the rate of increase of the disease organisms.

\section{Materials and methods}

An experiment was laid down in two young beech stands, aged 32 and 37 years, to follow over an eight year period the development of BBD symptoms in plots subjected to different thinning regimes. Both sites were first rotation beech plantations over chalk downland in southern England. At the beginning of the experiment, the 37 year old crop showed few symptoms of BBD. This reflected the low incidence of the causal organisms, and was fypical of Friston beat, Bedgebury Forest, where the stand was situated. The 32 year old crop showed a low level of disease within the stand, but was situated in Queen Elizabeth Forest where many stands were affected to various extents by BBD (fig. 1).

At the time the experiment was laid down, one hectare contained about 3500 stems with diameter over $75 \mathrm{~mm}$ at breast height, $1.3 \mathrm{~m}$ (diam bh). Four thinning regimes were included in the experiment: $A$, unthinned, $B$, light thinning, $C$, heavy thinning, $D$, extreme thinning. At each site the treatment plots were replicated three times in randomized blocks. Plot size was $35 \mathrm{~m}$ square, with an inner assessment area of $30 \mathrm{~m}$ square (0.09 ha).

Annual assessments were undertaken, usually towards the end of each growing season before autumnal effects predominated. The degree of infestation by $C$. fagisuga was the major disease symptom recorded (score 0 to 5 , where $0=$ absent, and $5=$ 


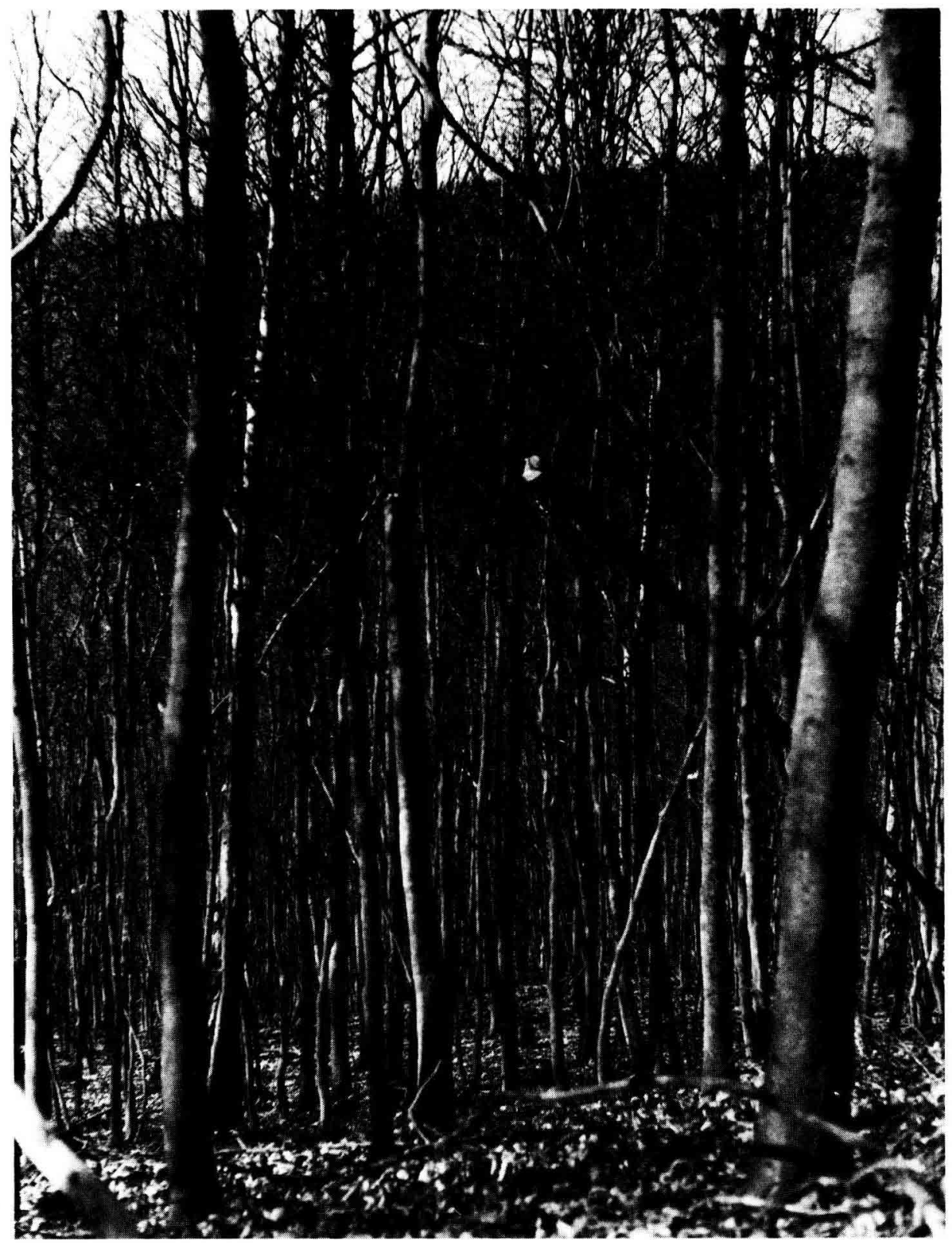

FIG. 1. - Plot of unthinned beech aged 40 years, site 2

Placette non élcaircie, âge des arbres 40 ans, station 2.

very heavy infestation) (fig. 2). Other disease symptoms (tarry spots, foliar chlorosis, etc.) were also recorded, as were numbers of trees dead due to invasion by Nectria coccinea (Pers. ex Fr.) Fries. Diam bh was recorded to indicate annual increment. 


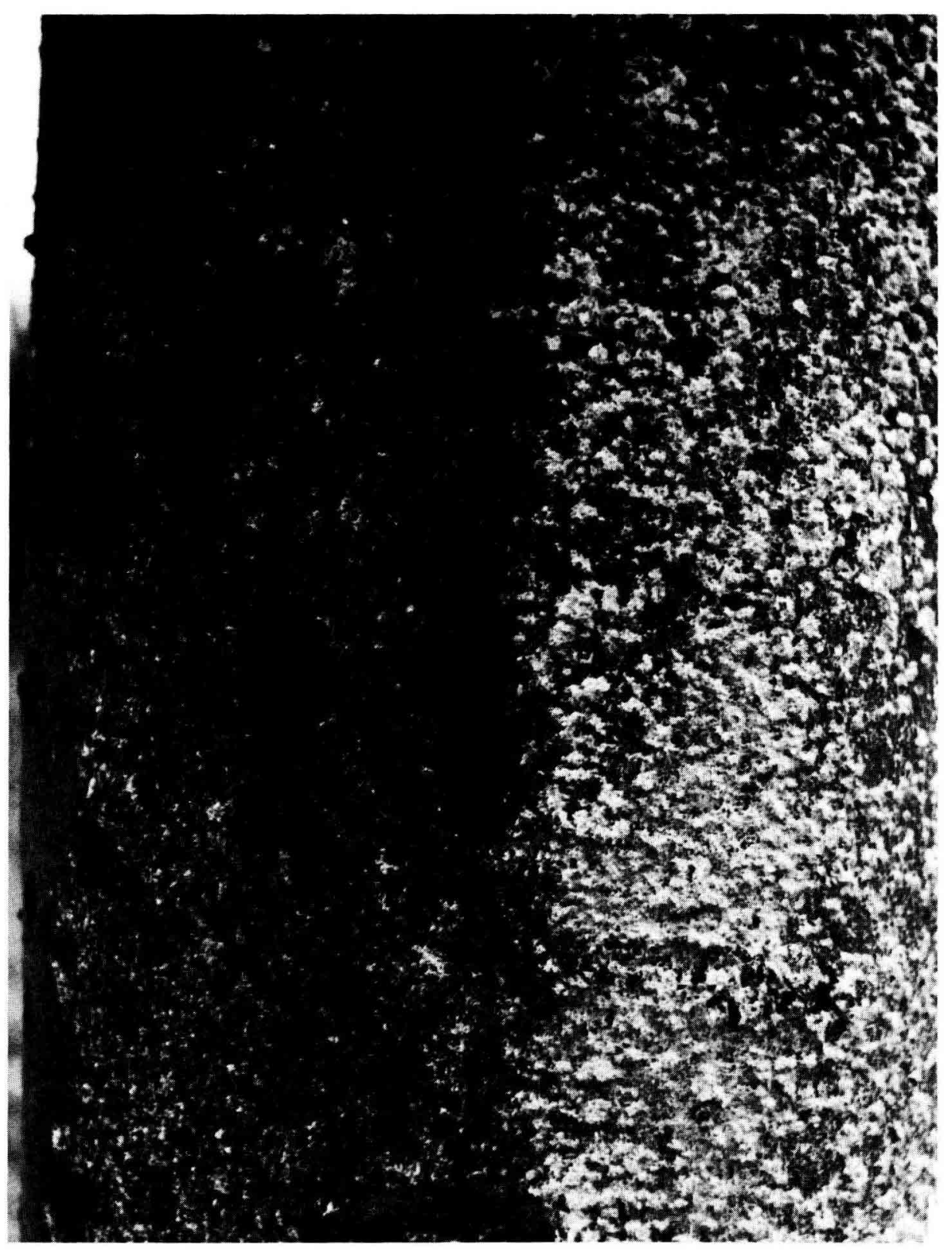

FIG. 2. - Dense current population of Cryptococcus fagisuga adjacent to previously heavily infested bark, now necrotic (with tarry spots), following infection by Nectria cocinea.

Population dense, acfuelle de C. fagisuga voisinant avec une zone nécrosée (avec suintements) ou une forte infestation a précédé l'infection par Nectria coccinea 


\section{Results}

Interim results after 3 and 5 years have bsen reported (Parker, 1975, 1976), and the final results after 8 years, presented here, confirm the earlier indications. Results for 1, 4, and 8 years after the experiment was laid down are compared in order to indicate the rate of increase in characters assessed.

In table 1 there is a comparison of the density of the crop for each treatment after thinning, expressed as the percentage number of stems from the original crop that remained. Thus for treatment $B$, approximately 30 p. 100 of the number of stems were removed, for treatment $C$ about 50 p. 100, and for treatment $D$ about 65 p. 100 were removed.

\section{TABLE 1}

Density of crop after thinning treatments

Densité des tiges après éclaircie

\begin{tabular}{|c|c|c|c|c|c|c|c|c|}
\hline \multirow{2}{*}{$\begin{array}{l}\text { Location } \\
\text { Treatment }\end{array}$} & \multicolumn{4}{|c|}{ Site 1 (age 37 years) } & \multicolumn{4}{|c|}{ Site 2 (age 32 years) } \\
\hline & A & B & $\mathrm{C}$ & D & A & B & $\mathrm{C}$ & $D$ \\
\hline $\begin{array}{c}\text { Mean p. } 100 \text { No. of } \\
\text { stems remaining } \ldots\end{array}$ & 100 & 70 & 55 & 40 & 100 & 67 & 38 & 33 \\
\hline
\end{tabular}

In table 2 there is a comparison of mean diam bh for each treatment, showing increased increment with time, and illustrating the direct host response to thinning.

TABLE 2

Mean diam bh $(\mathrm{mm})$

Diamètre moyen $(\mathrm{mm})$ à 1,3

\begin{tabular}{|c|c|c|c|c|c|c|c|c|}
\hline \multirow{2}{*}{$\begin{array}{l}\text { Location } \\
\text { Treatment }\end{array}$} & \multicolumn{4}{|c|}{ Site 1} & \multicolumn{4}{|c|}{ Site 2} \\
\hline & A & B & C & $\mathrm{D}$ & A & B & C & $\mathrm{D}$ \\
\hline \multicolumn{9}{|l|}{ Thinning } \\
\hline $\begin{array}{l}+1 \text { year } \ldots \ldots \ldots \ldots \ldots \ldots \ldots \\
+4 \text { years } \ldots \ldots \ldots \ldots \ldots \ldots \ldots \\
+8 \text { years } \ldots \ldots \ldots \ldots \ldots \ldots\end{array}$ & $\begin{array}{l}150 \\
161 \\
171\end{array}$ & $\begin{array}{l}152 \\
163 \\
176\end{array}$ & $\begin{array}{l}154 \\
166 \\
183\end{array}$ & $\begin{array}{l}158 \\
171 \\
186\end{array}$ & $\begin{array}{r}97 \\
108 \\
120\end{array}$ & $\begin{array}{r}98 \\
109 \\
119\end{array}$ & $\begin{array}{l}101 \\
118 \\
134\end{array}$ & $\begin{array}{l}103 \\
118 \\
132\end{array}$ \\
\hline
\end{tabular}

In table 3 there is a comparison of an index derived from mean $C$. fagisuga scores for each treatment, which illustrates the general increase of the insect populations seemingly irrespective of crop density. On pooling the data for all treatments, it is apparent that at site 1 ( 37 years old at thinning), where there was a lower overall incidence of $C$. fagisuga, 59 p. 100 of the trees bore zero infestation one season after thinning, and the overall mean $C$. fagisuga infestation index increased from 0.63 to 1.91 after 8 years. At site 2 ( 32 years old at thinning) 36 p. 100 of trees bore zero infes- 
TABLE 3

Index of Cryptococcus fagisuga infestation Index d'infestation de C. fagisuga

\begin{tabular}{|c|c|c|c|c|c|c|c|c|}
\hline \multirow{2}{*}{$\begin{array}{l}\text { Location } \\
\text { Treatment }\end{array}$} & \multicolumn{4}{|c|}{ Site 1} & \multicolumn{4}{|c|}{ Sife 2} \\
\hline & A & B & C & D & A & B & $C$ & $D$ \\
\hline $\begin{array}{l}\text { Thinning } \\
\quad+1 \text { year. } \ldots \ldots \ldots \ldots \ldots \ldots \\
+4 \text { years } \ldots \ldots \ldots \ldots \ldots \\
+8 \text { years } \ldots \ldots \ldots \ldots \ldots\end{array}$ & $\begin{array}{l}0.59 \\
1.72 \\
1.93\end{array}$ & $\begin{array}{l}0.64 \\
1.56 \\
2.07\end{array}$ & $\begin{array}{l}0.60 \\
1.41 \\
1.88\end{array}$ & $\begin{array}{l}0.72 \\
1.61 \\
1.71\end{array}$ & $\begin{array}{l}0.97 \\
1.97 \\
2.31\end{array}$ & $\begin{array}{l}1.08 \\
2.16 \\
2.33\end{array}$ & $\begin{array}{l}0.84 \\
2.35 \\
2.40\end{array}$ & $\begin{array}{l}1.12 \\
1.99 \\
2.37\end{array}$ \\
\hline
\end{tabular}

tation one season after thinning, and the overall mean $C$. fagisuga infestation index increased from 1.01 to 2.35 , thus showing a similar build-up in $C$. fagisuga populations, allowing for the relative initial difference.

In table 4 there is a comparison of the cumulative number of trees for each treatment that have died due apparently to BBD. An analysis of variance on the percentage of trees (data transformed to angles) in each plot dying from BBD within the 8 year experiment showed that proportionately fewer trees died in the extremely thinned plots (treatment $D, P<0.05$ ) compared with the other three treatments. It is evident from the raw data that 83 p. 100 of the dead trees were below the mean diam bh for their plot in the year of their death. Nevertheless, recruitment of trees into $C$. fagisuga infestation score classes 4 and 5 seemed to occur irrespective of diam bh.

\section{TABLE 4}

Cumulative number of trees dying from $B B D$

Nombre cumulé d'arbres fués par la maladie

\begin{tabular}{|c|c|c|c|c|c|c|c|c|}
\hline \multirow{2}{*}{$\begin{array}{l}\text { Location } \\
\text { Treatment }\end{array}$} & \multicolumn{4}{|c|}{ Sife 1} & \multicolumn{4}{|c|}{ Site 2} \\
\hline & A & B & C & $D$ & A & B & $C$ & D \\
\hline \multicolumn{9}{|l|}{ Thinning } \\
\hline+1 year. & 0 & 0 & 0 & 0 & 0 & 0 & 0 & 0 \\
\hline+4 years...... & 16 & 6 & 6 & 1 & 2 & 2 & 1 & 0 \\
\hline+8 years...... & 36 & 36 & 17 & 8 & 26 & 33 & 21 & 7 \\
\hline
\end{tabular}

N. B. Assessments were made annually, so that it was usually evident if a tree had died with associated symptoms of BBD (cumulative counts recorded here), or from other causes such as suppression (a further nineteen trees at site 1 , and nine trees at site 2 ).

\section{Discussion}

It is evident from this experiment that the intensity of a first thinning of young beech had no significant effect on the rate of increase of $C$. fagisuga infestation within a stand. Populations progressed at both sites from an initial low level, to a generally 
moderate incidence after 8 years, whether in the unthinned or very heavily thinned plots. The raw data not presented here, together with general observations, indicated that there was no apparent effect of thinning on the rate of increase of $C$. fagisuga infestation on individual trees, or on spread to and colonization of uninfested trees. These conclusions relate only to pure $F$. sylvatica crops in approximately the 30 to 45 years age range, planted on first rotation chalk downland sites, although it is possible that similar developments occur under different site conditions. It is in this age range $F$. sylvatica crops appear to reach their maximum susceptibility to infestation by $C$. fagisuga.

As previously noted (Parker, 1974, 1975) it is often the vigorous pure beech crops of high yield class that are the earliest to become infested within a newly forested area, and which subsequently develop a high level of BBD if left unthinned. In this experiment the majority of deaths attributable to BBD occurred between 5 and 8 years after thinning, when trees in the thinned plots had been able to make compensatory growth to recover some of the proportion of stand volume lost through the extraction of thinnings. The fact that a significantly smaller proportion of trees had succumbed to BBD in the extremely thinned plots suggests that, 8 years after the experiment had been laid down, these plots had still not recovered to the extent of full competitiveness between trees. Nevertheless, at that time the $C$. fagisuga infestation index had increased to similar levels irrespective of thinning regime. It therefore appears likely that competition within a stand lowers the host's physiological condition such that the effects of a given level of $C$. fagisuga infestation and associated Nectria infection of beech bark are enhanced, leading to an increased risk of mortality by BBD.

There is increasing evidence from observations in $F$. sylvatica plantations of southern England, that BBD incidence in a stand reaches a peak and then subsides naturally, so that even in apparently bad BBD situations the growth of surviving trees soon compensates for disease losses, and forest cover is retained. Thus, in one respect $B B D$ is acting as a natural thinning agent at a time when increased management intervention would be unprofitable.

Reçu pour publication en décembre 1979.

\section{Résumé}

Les fendances de la population de Cryptococcus fagisuga Lindinger après différentes intensités d'éclaircie dans les jeunes peuplements de hêtre

Les pullulations de $C$. fogisuga et autres symptômes de la maladie de l'écorce du hêtre ont été enregistrés annuellement pendant 8 ans, sur des placettes ayant subi des régimes différents d'éclaircies. L'intensité de l'éclaircie n'a pas eu un effet apparent sur l'augmentation de C. fagisuga dans une parcelle. L'augmentation de C. fagisuga sur des arbres individuels intervient indépendamment de leur diamètre. La compétition dans le peuplement peut favoriser la maladie, conduisant à un nombre d'arbres morts plus important par une résistance amoindrie de l'hôte. On suggère que les pertes résultant de la maladie dans les parcelles jeunes se compensent après quelques années par la croissance des arbres survivants. 


\section{Zusammenfassung}

\section{Der Einfluss der Durchforstungsintensität auf das Auftreten von Cryptococcus fagisuga Lindinger in jungen Buchenbeständen}

Der Befall durch Cryptococcus fagisuga und die Symptome der Buchen-Rindennekrose (beech bark disease, BBD) wurden in Probeparzellen nach unterschiedlicher Durchforstung 8 Jahre lang beobachtet. Die jeweilige Durchforstungsintensität schien die Vermehrung von $C$. fagisuga in den Beständen nicht zu beeinflussen. Die Zunahme von $C$. fagisugo an einzelnen Bäumen war unabhängig von deren Stammdurchmesser. Möglicherweise sind Konkurrenz und dadurch verringerte Resistenz Ursachen dafür, dass mehr Bäume durch die Krankheit absterben. Es sieht jedoch so aus, als ob die durch die Buchen - Rindennekrose verursachten Verluste in jungen Beständen innerhalb einiger Jahre durch Wachstumszunahme der überlebenden Bäume wettgemacht würden.

\section{References}

BARTER G. W., 1947. The Beech scale. Forest Insect Investigations Bi-monthly Progress Report. Science Service, Dept. Agric., Ottawa, 3 (4), 1.

CROSBY D. and BJORKBOM J. C., 1958. Timely salvage can reduce losses from Beech scale Nectria attack. For. Res. Note, N'theost For. Exp. Sta., 82, 4 p.

DUCHESNE M. C., 1909. The Beech coccus (Cryptococcus fagi). Q. Jl. For., 3, 345-350.

EHRLICH J., 1934. The Beech bark disease, a Nectria disease of Fagus following Cryptococcus fagi (Baer.). Can. J. Res., 10, 593-692.

LINDINGER L., 1936. Neue Beiträge zur Kenntnis der Schildläuse (Coccidae). Ent. Z., 49, 444.

PARKER E. J., 1974. Beech bark disease. Foresi Rec., Lond., 96, 15 p.

PARKER E. J., 1975. Beech bark disease. Ph. D. thesis, Univ. Surrey, 161 p.

PARKER E. J., 1976. Beech bark disease. In Rep. For. Res., Lond., 1976, 32-34.

PEACE T. R., 1954. The control and avoidance of forest tree diseases. In Rep. For. Res., Lond., 1953, $62-70$. 